\title{
Prevalence and characterization of urinary tract infection among pregnant women from the Eje Cafetero (Coffee Axis), 2015-2018
}

\begin{abstract}
Introduction: Bacterial infections of the urinary tract are the most common infections among pregnant women; They are associated with the anatomical and physiological changes typical of pregnancy. Timely diagnosis and treatment is mandatory, due to potential maternal-fetal complications.
\end{abstract}

Objective: to estimate the prevalence and characterization of urinary infections in pregnant women from the Coffee Region (Colombia).

Materials and methods: Cross-sectional study. 473 pregnant women over 18years old, with symptoms of urinary tract infection and positive urine culture; admitted to the prenatal outpatient clinic, the emergency department or hospitalized were included. The research was carried out in three private level III care hospitals in three cities of the Eje Cafetero (Coffee Axis) (Armenia, Pereira, and Manizales); between July 2015 and June 2018. Description was stratified by age (18 to 29 years, 30 to 39 years and over 40 years). Descriptive statistics were used to analyze the information. Sample calculation and simple random selection were made.

Results: the mean age of the participants was 26.58 7 7.49years (minimum 18 and maximum 48). The prevalence of urinary infection was $9.72 \%$. The age group with the highest frequency of urinary infection was 18 to 29 -year-old $(45.65 \%)$, and the lowest frequency was in those over $40(17.39 \%)$. Women in their second trimester were the most affected ones. (52.17\%). The germ found the most in urine culture was Escherichia coli (73.91\%), followed by Klebsiella spp (8.69\%). $2.74 \%$ presented asymptomatic bacteriuria, $5.07 \%$ acute cystitis and $1.9 \%$ acute pyelonephritis. The rate of recurrent urinary infection detected was $2.53 \%$.

Conclusion: There is a significant prevalence of urinary infection in pregnant women from the Coffee Region, close to one-tenth of the population, characterized mainly by acute cystitis; with predominance of Escherichia coli and Klebsiella spp. germs early interventions are required to establish both an immediate diagnostic and therapeutic plan.
Volume 9 Issue 2 - 202 I

\section{Franklin J Espitia De La Hoz}

Department of Urogynecology/Clinical sexology, Hathor, Clínica Sexológica, Colombia

Correspondence: Franklin J Espitia De La Hoz, Department of Urogynecology/Clinical sexology, Hathor, Clínica Sexológica, Colombia, Tel 3/27436696, Email espitiafranklin@hotmail.com

Received: April 27, 2021 | Published: May 07, 2021

Keywords: prevalence, cystitis, bacteriuria, pyelonephritis, pregnant women

\section{Introduction}

Urinary infection is microbial colonization and multiplication, usually bacterial, along the urinary tract, with or without symptoms. ${ }^{1}$ Throughout their lives, more than half of women will have at least one urinary infection; ${ }^{2}$ being much more frequent during pregnancy, ${ }^{3}$ and becoming one of the most common infectious complications in pregnancy. Urinary infections are classified by the site of infection, including urine (bacteriuria), bladder (cystitis), or kidney (pyelonephritis); ${ }^{4}$ although traditionally they have been classified, depending on whether they affect the proximal part (upper urinary tract infection) or the distal part (lower urinary tract infection). ${ }^{5}$ The incidence of asymptomatic bacteriuria and acute cystitis during pregnancy is $2-10 \%$ and $1-4 \%$, respectively. ${ }^{6,7}$ Around $20-40 \%$ of pregnant women with asymptomatic bacteriuria will develop pyelonephritis during pregnancy. ${ }^{8-10}$ Acute pyelonephritis in pregnancy is the most severe picture of a urinary infection, which can lead to maternal and perinatal complications, ${ }^{9,11}$ it usually occurs in $1-2 \%$ of pregnant women, particularly during the end of the second and beginning of the third trimester. ${ }^{12-14}$ It is usual that a single microorganism is responsible for the urinary infection, in more than $95 \%$ of cases; being the most frequent germ Escherichia coli (75-80\%); the remaining 20-25\% includes Enterococcus spp, Klebsiella spp, Proteus mirabilis, Proteus vulgaris, Pseudomonas aeruginosa Staphylococcus saprophyticus, among others. ${ }^{3,15,16}$ In the diagnosis, clinical evaluation is always first, prevailing over tests and office studies, which should only be considered to guide the presumptive diagnosis. ${ }^{17}$ Urine examination is especially useful, since leukocytes, pyocytes and red blood cells can be observed in up to $40-60 \%$ of urinary infections. ${ }^{18}$ Pyuria (presence of more than 5 leukocytes per field in centrifuged urine, equivalent to the count of more than 20 leukocytes $/ \mathrm{mm}^{3}$ in uncentrifuged urine), has a sensitivity of $80-95 \%$ and specificity of $50-76 \%{ }^{17,19}$ Bacteriuria (detected by Gram stain, one or more bacteria in uncentrifuged urine) is less sensitive (40-70\%) but more specific (85-95\%). ${ }^{19}$ Test strips are useful for measuring leukocyte esterase and/or nitrites, they are used as a diagnostic approach; they have a specificity of $59-96 \%$ and sensitivity of $68-98 \%$ for the detection of uropathogens whose concentration is equivalent to $\geq 105 \mathrm{CFU} / \mathrm{mL} .{ }^{20}$ The strips used for the measurement of nitrites have a sensitivity of $19-45 \%$ and a specificity of $95-98 \% .^{20}$ 
The joint performance of these two tests increases the sensitivity to $88-92 \%$ and specificity to $78-98 \% .^{20}$

Urine culture is the gold standard for the diagnosis of any form of urinary infection. ${ }^{19}$ It is considered positive when there is a report of more than $105 \mathrm{CFU} / \mathrm{mL} .{ }^{21}$ In the Eje Cafetero (Coffee Axis) there is limited information on the incidence and prevalence of urinary infections in pregnant women; that is why the objective of this research was to estimate the prevalence and characterization of urinary infections in pregnant women from the Eje Cafetero (Coffee Axis); women in prenatal care, who consulted the emergency services or were hospitalized, in three private level III care clinics.

\section{Materials and methods}

\section{Design and population}

Descriptive cross-sectional observational study. Pregnant women over 18 years of age, with symptoms of urinary tract infection (dysuria, chills, fever, stranguries, lumbar pain, frequency, urgency, urgency, macroscopic hematuria, suprapubic pain, positive percussion fist, cloudy urine and / or smelly) and positive urine culture were included; Eje Cafetero (Coffee Axis) inhabitants, who were admitted to the prenatal outpatient clinic, to the emergency service or who were hospitalized, in three highly complex private clinics, in each of the main cities of the Coffee Region (Armenia, Pereira and Manizales). These institutions serve the population of the contributory and subsidized regimes of Colombia's health care system. This study was conducted between July 1, 2015 and June 30, 2018. Women with genital bleeding at the time of the examination, twin pregnancy (due to its association with an increase in the incidence of urinary tract infection), isthmic-cervical insufficiency, anatomical malformations of the urinary tract, fetal malformations (in order not to increase stress maternal), psychiatric illnesses, neurological deficit, mental retardation, antibiotic treatment in the previous 7 days and a history of cancer. A sample of 406 participants was derived from the universe of pregnant women who entered the study period; $95 \%$ confidence interval, and a $3 \%$ error, however, 473 women were included, to cover losses. Simple random sampling was applied for the selection of pregnant women, using a computer program.

\section{Procedure}

In each of the participating clinics, pregnant women who were in prenatal care, visited the emergency care unit or were hospitalized in the maternity service with an apparent normal pregnancy, course were identified by the treating obstetrician. The following international classification of diseases (ICD10) was used for disease classification: O23.0 Kidney infections in pregnancy; O23.1 Infections of the bladder in pregnancy; O23.3 Infection of other parts of the urinary tract in pregnancy; O23.4 Unspecified urinary tract infection in pregnancy. A general practitioner, expert in pregnant care, part of the research team, oversaw the evaluation of each pregnant woman, to determine if she met the eligibility criteria of the study. If pregnant woman fulfilled the inclusion criteria, she was informed of the objectives of the research, as well as the purpose of the results, and she was asked to sign the informed consent. Once consent was obtained, the nursing assistant in charge of taking the sample oversaw the genital washing process, to guarantee the correct collection of the urine sample (the sample was collected from the middle of the urine stream). A complete urine test was performed and a urine culture with an antibiogram was performed. The diagnosis of urinary infection is confirmed through a positive urine culture performed with CHROMID ${ }^{\circledR}$ CPS ${ }^{\circledR}$ Elite reagent medium, which is processed by counting sowing and, depending on the number of colonies; was read by a bacteriologist specialized in microbiology and analyzed by an obstetrician to establish the diagnosis. The isolated bacterial strains were analyzed on identification cards for genus and species, and on another card for sensitivity to the following antibiotics: Ampicillin, Ampicillin-sulbactam, Amoxicillin-clavulonate, Aztreonam, Cephalothin, Ceftriaxone, Amikacin, Phosphomycin, Gentamicin, Meropenem, Nitrofurantoin, Piperacillin-tazobactam, Trimethoprimsulfamethoxazole. The nursing assistants, in charge of data collection, searched for information in the clinical history; those with missing data were interviewed by the head nurse of the prenatal control program. A questionnaire designed by the researchers was applied, through which the information on the characteristics and clinical manifestations was uniformly extracted. The data was digitized into an Excel 12.0 spreadsheet, from where it was exported, stored, and processed in a database of the SPSS ${ }^{\circledR}$ v20 statistical program.

\section{Measured variables}

socio-demographic, gyneco-obstetric history (parity, history of abortion, weeks of gestation, trimester of pregnancy), personal history, clinical manifestations, entities related to urinary tract infection, germs reported in urine culture, antimicrobial sensitivity profile, as well as the prevalence rate, which was calculated with respect to the number of pregnant women with urinary infection over the total number of participants.

\section{Statistical analysis}

Descriptive statistics were used to analyze the information. In the quantitative variables, the mean, standard deviation (SD), median and range were calculated; in the qualitative, proportions were used.

\section{Ethical aspects}

The research was approved by the Medical Ethics Committee, by act No. 0123; The ethical principles of the Declaration of Helsinki and Resolution 8430 of 1993 of the Ministry of Health of Colombia were followed. The confidentiality of information, anonymity, and privacy of the data of the patients and the research team were guaranteed.

\section{Results}

A total of 734 pregnant women were invited to participate in the research; of these, $107(14.57 \%)$ did not meet the inclusion criteria, $31(4.22 \%)$ refused to participate, $79(10.76 \%)$ had genital bleeding, twin pregnancy, isthmic-cervical insufficiency, anatomical malformations of the urinary tract, fetal malformations or received antibiotic treatment in the previous 7 days, 44 (5.99\%) did not provide complete information, therefore they were excluded. The final analysis was performed with a total of 473 (64.44\%) pregnant women. The sociodemographic characteristics of the total population of pregnant women reported that the average age of the participants was $26.58 \pm 7.49$ years, median of 25 years (range between 18 and 48). The majority $(86.89 \%)$ came from the urban area, affiliated with the contributory health care plan (83.93\%) and their religion was Catholic $(89.85 \%)$ (Table 1). The gestational age, at the time of diagnosis of the urinary infection, reported an average of $23.71 \pm 4.58$ weeks, with a median of 21 weeks, (range between 9 and 39). The mean of prenatal controls reported a median of 3 (range between 1 and 7). The sexual and reproductive health history showed a median of 3 children (2 vaginally and 1 cesarean section per woman), ranging between 1 and 8 children. The multiparous to nulliparous ratio was $3: 1.80 .97 \%$ of the pregnant women affirmed having had more than three pregnancies, of which $83.81 \%$ were unplanned. The prevalence of abortions was 
$26.84 \%$, of these $1.47 \%$ were done through the voluntary interruption of pregnancy (VIP) and 6.29\% were induced and practiced under risky conditions (self-formulated drugs or in clandestine places).

Table I Sociodemographic characteristics in pregnant women, Eje Cafetero (Coffee Axis), Colombia, 20I5-20I8

\begin{tabular}{|c|c|}
\hline Variable and categories & n/proportion (\%) \\
\hline Age: $X \pm S D$ years & $26,58 \pm 7,49$ \\
\hline Age of partner: $X \pm S D$ & $29,74 \pm 6,13$ \\
\hline Weight: $X \pm D E ~ K g$ & $64,87 \pm 9,57$ \\
\hline Height: $X \pm D E C m s$ & $161,35 \pm 7,13$ \\
\hline $\mathrm{BMI}: \mathrm{X} \pm \mathrm{SD}$ & $25,14 \pm 6,38$ \\
\hline \multicolumn{2}{|l|}{ Ethnic group } \\
\hline Hispanics & $299(63,21)$ \\
\hline Afro descendants & $146(30,86)$ \\
\hline Indigenous & $28(5,91)$ \\
\hline \multicolumn{2}{|l|}{ Socioeconomic status } \\
\hline Low & $52(10,99)$ \\
\hline Middle & $335(70,82)$ \\
\hline High & $86(18,18)$ \\
\hline \multicolumn{2}{|l|}{ Civil Status } \\
\hline Married or Common Law & $318(67,23)$ \\
\hline Single & $82(17,33)$ \\
\hline Divorced & $56(11,83)$ \\
\hline Widows & $17(3,59)$ \\
\hline \multicolumn{2}{|l|}{ Scholarship } \\
\hline Primary & $4 \mathrm{I}(8,66)$ \\
\hline Secondary & $197(41,64)$ \\
\hline Technical & $116(24,52)$ \\
\hline Professionals & $119(25,15)$ \\
\hline \multicolumn{2}{|l|}{ Occupation } \\
\hline Employed & $94(19,87)$ \\
\hline Independent & $73(15,43)$ \\
\hline Unemployed & I0I $(21,35)$ \\
\hline Housewives & $205(43,34)$ \\
\hline
\end{tabular}

Sexual behavior reported that the average age of initiation of sexual life was $16.35 \pm 2.46$ years, with a median of 7 sexual partners (range between 1 and $\geq 20$ ). The average time spent with a partner was $8.15 \pm 3.16$ years. To the question, how many times did you have sex in the past week? (Period defined as the span of the previous seven days), a median of 2 was found (range between 0 and 5). In the personal history, the prevalence of gestational diabetes mellitus was $5.91 \%$, pregestational diabetes $2.74 \%$, vaginitis $27.69 \%$, vaginosis $35.94 \%$, clinical hypothyroidism $14.37 \%$ and chronic HT $1.69 \%$.
$56.87 \%$ had a history of at least one episode of urinary infection in the present pregnancy, and $65.96 \%$ in previous pregnancies. In 46 women the presence of urinary tract infection was diagnosed, for a prevalence of $9.72 \%$. The characterization by age groups was as follows: 18 to 29 years, 21 cases (45.65\%); from 30 to 39years, 17 cases $(36.95 \%)$ and over 40 years, 8 cases $(17.39 \%)$. In the first trimester the prevalence was $34.78 \%(\mathrm{n}=16 / 46)$, in the second $52.17 \%(\mathrm{n}=24 / 46)$ and in the third trimester $13.04 \%(n=6 / 46)$. Regarding clinical manifestations, dysuria $(71.73 \%)$ and frequency $(69.56 \%)$ predominated (Table 2$)$.

Table 2 Symptoms of urinary infection in pregnant women, Eje Cafetero (Coffee Axis), Colombia, 2015-2018

\begin{tabular}{ll}
\hline Clinical manifestations & $\mathbf{n}(\%)$ \\
\hline Asymptomatic & $13(28,26)$ \\
Dysuria & $33(71,73)$ \\
Pain in lumbosacral region & $13(28,26)$ \\
Suprapubic pain & $17(36,95)$ \\
Shaking chills & $20(43,47)$ \\
Fever & $22(47,82)$ \\
Pollakiuria & $32(69,56)$ \\
Tachycardia & $26(56,52)$ \\
Bladder tenesmus & $24(52,17)$ \\
Urinary urgency & $27(58,69)$ \\
\hline
\end{tabular}

In the urine culture, the germ most frequently detected was Escherichia coli (73.91\%), followed by Klebsiella spp (8.69\%) and, in third place, Enterococcus spp (6.52\%) (Table 3). Escherichia coli showed resistance to the antibiotics frequently used at the hospital level, such as ampicillin (67.64\%), cephalothin (55.88\%) and gentamicin $(52.94 \%)$; but higher sensitivity against piperacillintazobactam (94.11\%) and meropenem (91.17\%). The antimicrobial susceptibility profile of Escherichia coli is described in Table 4. A frequency of $11.76 \%$ of Escherichia coli producing extended spectrum $\beta$-lactamases (ESBL) was observed. When characterizing the 3 entities related to urinary infection, it was found that $2.74 \%(n=13 / 473)$ presented asymptomatic bacteriuria, $5.07 \%(n=24 / 473)$ acute cystitis and $1.9 \%(n=9 / 473)$ Acute pyelonephritis. Recurrent urinary infection was detected in $2.53 \%(\mathrm{n}=12 / 473)$. In obstetric complications, a threat of abortion was found, $20.93 \%$, anemia $18.81 \%$, threat of premature birth $11.83 \%$, intrauterine growth restriction $10.35 \%$, pre-eclampsia $9.72 \%$ and premature rupture of the membranes ovular $7.18 \%$.

Table 3 Characterization of uropathogens in pregnant women with urinary infection, Eje Cafetero (Coffee Axis), Colombia, 20I5-2018

\begin{tabular}{ll}
\hline Clinical manifestations & $\mathbf{n}(\%)$ \\
\hline Escherichia coli & $34(73,91)$ \\
Klebsiella spp & $4(8,69)$ \\
Enterococcus spp & $3(6,52)$ \\
Proteus spp & $2(4,34)$ \\
Pseudomonas spp & $\mathrm{I}(2,17)$ \\
Enterobacter spp & $\mathrm{I}(2,17)$ \\
Streptococcus spp & $\mathrm{I}(2,17)$ \\
\hline
\end{tabular}


Table 4 Characterization of uropathogens in pregnant women with urinary infection, Eje Cafetero (Coffee Axis), Colombia, 20I5-2018

\begin{tabular}{|c|c|c|}
\hline Antibiotics & Sensitivity & n (\%) \\
\hline \multirow{3}{*}{ Amoxicillin-clavulanate } & $\mathrm{S}$ & 73.52 \\
\hline & I & 2.94 \\
\hline & $\mathrm{R}$ & 23.52 \\
\hline \multirow{3}{*}{ Ampicillin } & $\mathrm{S}$ & 67.64 \\
\hline & I & 5.88 \\
\hline & $\mathrm{R}$ & 26.47 \\
\hline \multirow{3}{*}{ Ampicillin-sulbactam } & $\mathrm{S}$ & 64.70 \\
\hline & I & 5.88 \\
\hline & $\mathrm{R}$ & 29.41 \\
\hline \multirow{3}{*}{ Aztreonam } & $\mathrm{S}$ & 91.17 \\
\hline & I & 2.94 \\
\hline & $\mathrm{R}$ & 5.88 \\
\hline \multirow{3}{*}{ Cephalothin } & $\mathrm{S}$ & 55.88 \\
\hline & I & 14.70 \\
\hline & $\mathrm{R}$ & 29.41 \\
\hline \multirow{3}{*}{ Ceftriaxone } & $\mathrm{S}$ & 41.17 \\
\hline & I & 14.70 \\
\hline & $\mathrm{R}$ & 44.11 \\
\hline \multirow{3}{*}{ Amikacin } & $\mathrm{S}$ & 61,76 \\
\hline & I & 11,76 \\
\hline & $\mathrm{R}$ & 26,47 \\
\hline \multirow{3}{*}{ Fosfomycin } & $\mathrm{S}$ & 91.17 \\
\hline & I & 5.88 \\
\hline & $\mathrm{R}$ & 2.94 \\
\hline \multirow{3}{*}{ Gentamicin } & $\mathrm{S}$ & 52.94 \\
\hline & I & 20.58 \\
\hline & $\mathrm{R}$ & 26.47 \\
\hline \multirow{3}{*}{ Meropenem } & $\mathrm{S}$ & 91.17 \\
\hline & I & 5.88 \\
\hline & $\mathrm{R}$ & 2.94 \\
\hline \multirow{3}{*}{ Nitrofurantoin } & $\mathrm{S}$ & 82.35 \\
\hline & I & 11.76 \\
\hline & $\mathrm{R}$ & 5.88 \\
\hline \multirow{3}{*}{ Piperacillin-tazobactam } & $\mathrm{S}$ & 94.11 \\
\hline & I & 2.94 \\
\hline & $\mathrm{R}$ & 2.94 \\
\hline \multirow{3}{*}{$\begin{array}{l}\text { Trimetoprim- } \\
\text { sulfametoxazol }\end{array}$} & $\mathrm{S}$ & 73.52 \\
\hline & I & 17.64 \\
\hline & $\mathrm{R}$ & 8.82 \\
\hline
\end{tabular}

\section{Discussion}

In this investigation, a prevalence of urinary infection in pregnancy of $9.72 \%$ was found. The age group where the highest frequency of infection was observed was that of 18 to 29 years $(45.65 \%)$, the second trimester being the most affected one $(52.17 \%)$, while the germ presents more frequently, in the Urine culture, it was Escherichia coli $(73.91 \%)$. In the clinical manifestations, dysuria (71.73\%) predominated, followed by frequency $(69.56 \%)$. In our findings, the prevalence of urinary tract infection in pregnant women is higher than the $1.78 \%$ reported by Vallejos et al. ${ }^{22}$ in 83 participants in Puebla (Mexico) or the 7.4\% published by Quirós-Del Castillo et al. ${ }^{23}$ in Lima (Peru); although much lower than the $26 \%$ registered by Parveen et al. ${ }^{24}$ in Dhaka (South Asia), or the $21.7 \%$ described by Akinloye et al. ${ }^{25}$ in 300 pregnant women from Ibadan (Nigeria).
The difference is explained both by the divergence in the inclusion and exclusion criteria, as well as because the pregnant women were cared for in different institutions, without homogenizing follow-up. Regarding the prevalence of urinary infection per quarter, our results are similar to those of Onuh et al. ${ }^{26}$ in 542 pregnant women from Abakaliki, Ebonyi State, (Nigeria), who reported a high prevalence of urinary tract infection in the second trimester compared to the first and third trimesters; but different from those of Leigh et al. ${ }^{27}$ who reported an increase in the frequency of urinary tract infection in the third trimester compared to the first and second trimesters of pregnancy.

Escherichia coli has been identified in $80-85 \%$ of urinary tract infections, ${ }^{28}$ which is slightly higher than the $73.91 \%$ in our study, but much more than the $64 \%$ described by Ferreira et al. ${ }^{29}$ in 50 hospitalized pregnant women, in Neiva (Colombia), but totally higher than the $55.6 \%$ published by Autún et al. ${ }^{30}$ in Tlalnepantla (México). ${ }^{30}$ In Tlalnepantla (Mexico). The differences are explained by sociodemographic characteristics, as well as a history of medical illnesses. In our study, the antimicrobial sensitivity profile of Escherichia coli is resistant to ampicillin in $67.64 \%$, to cephalothin in $55.88 \%$, to ceftriaxone in $44.11 \%$ and to gentamicin in $5294 \%$, which are the most frequently used antibiotics in our environment. Resistance to amoxicillin-clavulonate, ampicillin-sulbactam and trimethoprimsulfamethoxazole, was less than $30 \%$, and less than $10 \%$ of the strains were resistant to aztreonam, fosfomycin, meropenem and piperacillintazobactam. The resistance to nitrofurantoin reached $82.35 \%$. These findings are lower than that reported by Ferreira et al. ${ }^{29}$ Escherichia coli, producing extended spectrum $\beta$-lactamases (ESBL), was isolated by Quirós-Del Castillo et al. ${ }^{23}$ in $16.3 \%$ of pregnant women, in contrast to our $11.76 \%$, or the $47 \%$ published by Rizvi et al. ${ }^{31}$ This is explained by its relationship with the adequate prescription of antibiotics in our institutions, which has been promoted in the last decade, thanks to the exercise carried out in Bogotá. ${ }^{32}$

When characterizing the 3 entities related to urinary infection, our results are not consistent with the $19.1 \%$ reported by Autún et al. ${ }^{30}$ or $13.8 \%$ published by Tomás-Alvarado et al. ${ }^{33}$ There is a paucity of data on acute cystitis in pregnancy, but available studies show that it ranges from $1-4 \% .^{34-36}$ The prevalence of acute pyelonephritis, in most reports, ranges between $0.5-2 \%$ of pregnancies, ${ }^{37-40}$ which is consistent with our findings. The performance of a urine culture, at the beginning of pregnancy, should be of routine use in prenatal control, and if it is positive, requesting the antimicrobial sensitivity profile is mandatory before proceeding to establish antibiotic therapy. ${ }^{41,42}$ They identified it as ESBL-producing Enterobacteriaceae, we report it as an epidemiological situation to evaluate, since it is a variable that is usually unknown in our country, particularly in pregnant women; therefore, our findings confirm the urgent need to establish an adequate control in the policies for antibiotics usage. The main strength of this research is that it is multicenter, which gives it the advantage of rapid recruitment, a larger number of participants and a faster development of the same, in addition to having a significant number of pregnant women. Among the limitations to be highlighted, we noted that the response to therapy was not evaluated, nor were the complications of urinary tract infection described in pregnancy. Regarding maternalfetal complications observed in this study, it remains unknown whether they are causally related to urinary tract infection or are the product of the bias of including reference institutions for high-risk pregnant women.

\section{Conclusion}

In pregnant women from the Coffee Region there is a significant prevalence of urinary infection, which is close to a tenth of the 
population, characterized mainly by acute cystitis; predominating the germs Escherichia coli and Klebsiella spp. Early interventions are required to establish both an immediate diagnostic and therapeutic plan to estimate the effect on the need for hospitalization and costs at the regional level. It is suggested to carry out multicenter studies involving a larger sample, which allows us to corroborate or contrast our results, to modify and adjust (as far as possible) the clinical guidelines for the diagnosis and treatment of urinary infection in pregnant women of the region.

\section{Funding}

The research was funded with the author's own resources, which were obtained from his midwifery shifts in the city of Armenia.

\section{Acknowledgments}

We thank the nursing staff, and especially the microbiology laboratory staff, for their constant support in each of our ambitious investigations. Dr. Sandra Milena Sánchez Gutiérrez, my teacher and tutor at the times when I most needed a friend and a teacher, at the Hospital Universitario Clínica San Rafael (Bogotá); and the research team at Hathor, Clínica Sexológica, in Armenia (Quindío).

\section{Conflicts of interest}

The authors declare that there is no conflict of interest.

\section{References}

1. Howes DS, Henry SM. Urinary Tract Infection, Female. 2005.

2. Foxman B, Barlow R, D Arcy H, et al. Urinary tract infection: self-reported incidence and associated costs. Ann Epidemiol. 2000;10(8):509-515.

3. Delzell JE Jr, Lefevre ML. Urinary tract infections during pregnancy. Am Fam Physician. 2000;61(3):713-721.

4. Levinson W, Jawetz E. Medical microbiology and immunology. 6th edn. New York. Lange Medical Books/McGraw-Hill; 2000:26

5. Gelabert MA. Infección urinaria y gestación: Definiciones e importancia del problema; 1:1-11.

6. North DH, Speed JE, Weinter WB, et al. Correlation of urinarytract infection with urinary screening at the first antepartum visit. J Miss State Med Assoc. 1990;31:331-333.

7. Andrews WW, Gilstrap LC. Urinary tract infections. In: Gleicher N,Buttino $\mathrm{L}$, editors. Principles and practice of medical therapies in pregnancy. 3rd edn. Stamford, CT: Appleton and Lange; 1998:913-917.

8. Duff P. Pyelonephritis in pregnancy. Clin Obstet Gynecol. 1984;27(1):1731 .

9. Foxman B. Epidemiology of urinary tract infections: incidence, morbidity, and economic costs. Am J Med. 2002;113(Suppl1A):5S-13S.

10. Bint AJ, Colina D. Bacteriuria of pregnancy - an update on significance diagnosis, and management. J Antimicrob Chemother. 1994; 33(supp A):93-97.

11. Cunningham FG, Lucas MJ. Urinary tract infections complicating pregnancy. Baillieres Clin Obstet Gynaecol. 1994;8(2):353-373.

12. Wing DA. Pyelonephritis in pregnancy: treatment options for optimal outcomes. Drugs. 2001;61(14):2087-2096.

13. Kiningham RB. Asymptomatic bacteriuria in pregnancy. Am Fam Physician. 1993;47(5):1232-1238.

14. Gilstrap LC 3rd, Cunningham FG, Whalley PJ. Acute pyelonephritis in pregnancy: an anterospective study. Obstet Gynecol. 1981; 57(4):409-413.
15. Stamm WE, Hooton TM. Management of urinary tract infections in adults. N Engl J Med. 1993;329(18):1328-1334.

16. Orrego-Marin CP, Henao-Mejia CP, Cardona-Arias JA. Prevalencia de infección urinaria, uropatógenos y perfil de susceptibilidad. Acta Médica Colombiana. 2014;39:352-358.

17. Bermúdez J, Solís K, Jiménez N. Manejo de infecciones del tracto urinario. Rev Costarricense Salud Pública. 2017; 26(1):1-10

18. Faro S, Fenner D. Urinary tract infections. Clin Obstet Gynecol. 1998; 41:744-754.

19. Fihn SD. Acute Uncomplicated urinary tract infection in women. $N$ Engl J Med. 2003;349(3):259-266.

20. Rushton HG. Urinary tract infections in children: epidemiology, evaluation and management. Pediatr Clin North Am. 1997;44:1133-1169.

21. Cortes JA, Perdomo D, Morales RA, et al. Guía de práctica clínica sobre diagnóstico y tratamiento de infección de vías urinarias no complicada en mujeres adquirida en la comunidad. Revista de la Facultad de Medicina. 2015;63(4):565-581.

22. Vallejos-Medic C, López-Villegas M, Enríquez-Guerra, et al. Prevalencia de infecciones de vías urinarias en embarazadas atendidas en el Hospital Universitario de Puebla. Enf Inf Microbiol. 2010;30(4):118-122.

23. Quirós-Del Castillo AL, Apolaya-Segura M. Prevalencia de infección de la vía urinaria y perfil microbiológico en mujeres que finalizaron su embarazo en una clínica privada de Lima, Perú. Ginecol Obstet Mex. 2018; 86(10):634-639.

24. Parveen K, Afroza M, Monowara B, et al. Prevalence of urinary tract infection during pregnancy. J Dhaka National Med Coll Hos. 2011;17(2):8-12.

25. Akinloye O, Ogbolu DO, Akinloye OM, et al. Asymptomatic bacteriuria of pregnancy in Ibadan, Nigeria: a re-assessment. Br J Biomed Sci. 2006;63(3):109-112.

26. Onuh SO, Umeora OUJ, Igberase Go, et al. Microbiological Isolates and sensitivity pattern of urinary tract infection in pregnancy in Benin City, Nigeria. Ebonyi Medical Journal. 2006;5(2):48-52.

27. Leigh D. Urinary Tract Infections. In: Parker MT, Darden BI, Editors. Topple and Wilson's Principles of bacteriology,Virology and Immunity. Decker BC, Philadelphia. 1989. p. 197-211

28. Gupta K, Hooton TM, Stamm WE. Increasing antimicrobial resistance and the management of uncomplicated community-acquired urinary tract infections. Ann Intern Med. 2001;135:41-50.

29. Ferreira FE, Olaya SX, Zúñiga $\mathrm{P}$, et al. Infección urinaria durante el embarazo, perfil de resistencia bacteriana al tratamiento en el hospital general de Neiva, Colombia. Rev Colomb Obstet Ginecol. 2005; 56(3):239-243.

30. Autún Rosado Dp, Sanabria Padróna VH, Cortés Figueroaa EH, et al. Etiología y frecuencia de bacteriuria asintomática en mujeres embarazadas. Perinatol Reprod Hum. 2016;29(4):148-151.

31. Rizvi M, Khan F, Shukla I, et al. Rising prevalence of antimicrobial resistance in urinary tract infections during pregnancy: necessity for exploring newer treatment options. J Lab Physicians. 2011;3(2):98-103.

32. López JJ, Garay AM. Estudio de utilización de antibióticos en el servicio de consulta externa de un hospital público en Bogotá, D.C. Rev Colomb Cienc Quím Farm. 2016;45(1):35-47.

33. Tomás-Alvarado E, Salas-Rubio MA. Prevalencia de bacteriuria en pacientes embarazadas de una unidad de medicina familiar del Estado de México. Atención Familiar. 2016;23(3):8083.

34. MacLean AB. Urinary tract infection in pregnancy. Int $J$ Antimicrob Agents. 2001;17:273-277. 
35. Wagenlehner FM, Weidner W, Naber KG. An update on uncomplicated urinary tract infections in women. Curr Opin Urol. 2009;19:368-374.

36. Sabharwal ER. Antibiotic susceptibility patterns of uropathogens in obstetric patients. N Am J Med Sci. 2012;4:316-319.

37. Schnarr J, Smaill F. Asymptomatic bacteriuria and symptomatic urinary tract infection in pregnancy. Eur J Clin Invest. 2008;38(Suppl. 2):50-57.

38. Jolley JA, Wing DA. Pyelonephritis in pregnancy: an update on treatment options for optimal outcomes. Drugs. 2010;70:1643-1655
39. Sharma P, Thapa L. Acute pyelonephritis in pregnancy: a retrospective study. Aust N Z J Obstet Gynaecol. 2007;47:313-315.

40. Hill JB, Sheffield JS, McIntire DD, et al. Acute pyelonephritis in pregnancy. Obstet Gynecol. 2005;105:18-23.

41. Espitia-De La Hoz FJ, Orozco-Santiago L. Infección urinaria recurrente en la mujer posmenopáusica. Rev Col de Menopausia. 2013;19(4):270-279.

42. Espitia-De La Hoz F. Infección de las vías urinarias en el embarazo. Rev Avances en Salud. 2020;(4)2:40-53. 